\title{
DESIGN AND VERIFICATION OF TRACTOR WHEELS EQUIPPED WITH AUTOMATICALLY EXTENSIBLE BLADES
}

\author{
Rudolf ABRAHÁM, Radoslav MAJDAN, Miroslav MOJŽIŠ \\ Slovak University of Agriculture in Nitra, Slovakia
}

This paper focuses on the possibility of increasing the drawbar pull of an agricultural tractor on the soil and grass-covered surface. We have compared the tractor tyre traction properties with a newly developed system of automatically extensible blades next to the tractor drive wheel tyres. The tractor with wheels equipped with auto-extensible blades reached a higher drawbar pull at an average of $70 \%$ on the soil and $80 \%$ on grass compared to tyres.

Keywords: tractor tyres, wheels equipped with auto-extensible blades, force sensor

The testing of new tractors used in agriculture is continuously increasing because these machines directly influence the results of agricultural production (Hujo et al., 2012 a). Agricultural tractors are losing a lot of energy by the slip of driving wheels. To reduce the tyre slip, tractors are loaded with a heavy weight, which increases the drawbar pull, but excessively increases soil compaction and tyre wear on a hard surface (Semetko, 1998, 2004). Nowadays, diesel oil and petroleum products belong to the most used fuels. Unfortunately, fossil fuels are non-renewable and exhaustible sources of energy (Müllerová et al., 2012). The increase of tractor drawbar pull influences the fuel consumption and emissions of exhaust gases.

To increase the drawbar pull and to reduce the soil compaction, some manufacturers recommend variable tyre inflation. Tyres are deflated to a pressure of $50 \mathrm{kPa}$ on the soil, and when moving on the road, they are inflated again to the required pressure. This method is mainly based on research results, which show an average decrease of contact pressure on the soil at an inflation pressure of $6 \mathrm{psi}(41 \mathrm{kPa})$ by about one-third in comparison with tyres inflated to 18 psi (125 kPa), Figure 1 (Schuler et al., 2000).

Negative effects of soil compaction have been observed for several years at the Department of Transport and

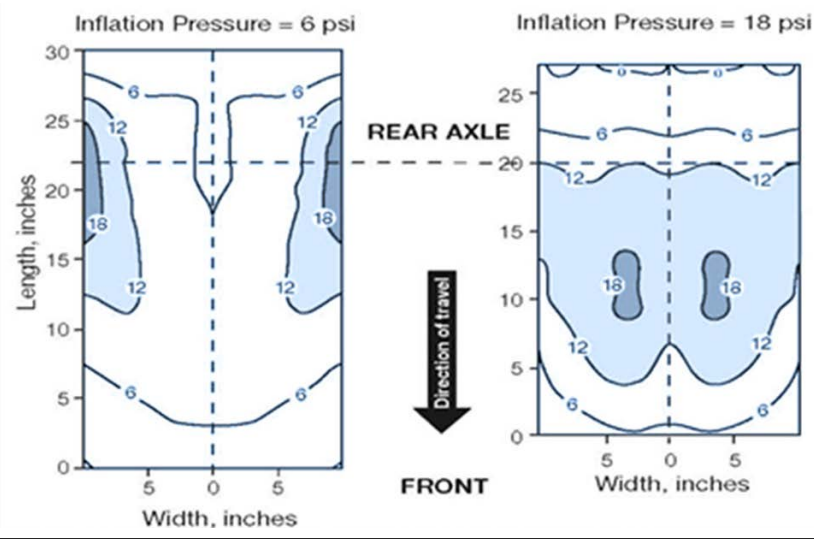

Figure 1 Pressure process in psi of the identical tyre with different filling pressures

Source: Schuler et al., 2000
Handling. Possible solutions are presented in two variants, which were compared by us in terms of drawbar pull. The first option consists of wheels equipped with autoextensible blades developed at the Department of Transport and Handling, and the second are steel boots that are used successfully on small tractors today.

\section{Material and methods}

\section{Wheels equipped with auto-extensible blades}

Wheels equipped with auto-extensible blades have been developed at the Department of Transport and Handling for the rear driving wheels of a tractor MINI 070. Wheels equipped with auto-extensible blades were designed according to the works published by Sloboda et al. (2008) and Jablonický et al. (2012). A big advantage is that they do not have to be removed from the tractor when passing on the road and also that they are automatically extended when the tractor driving wheels are slipping. Re-folding of driving blades occurs with the reverse movement of the tractor. The tractor needs not be equipped with additional load weights because they are replaced by wheels equipped with autoextensible blades. Wheels equipped with auto-extensible blades are mounted to the wheel disc, and according to Figure $2 \mathrm{a}, \mathrm{b}$, they consist of the following parts.

A support tube (1) is a basic part of the whole mechanism. It enables the remaining parts of the whole mechanism to be attached to each other. On the support tube, there are welded three locking tabs (2), three brackets (3) by which the whole mechanism is connected to the tractor wheel, and a driving disc (6) containing blades (5) mounted by means of ten pins. On the support tube, there are also welded spacer plates (4) through which the mechanism position is centred with respect to the tractor wheel disc. After the driving disc (6), the support tube contains a freely rotating disc for the control of blades (7). The blade control disc contains on its circumference twenty pressed guide pins by means of which blades move into the extended and retracted positions. On the other side of the blade control disc, there are four locking holes (9) to fix the position of blades in the retracted position. Three buffer plates (11), attached by six 

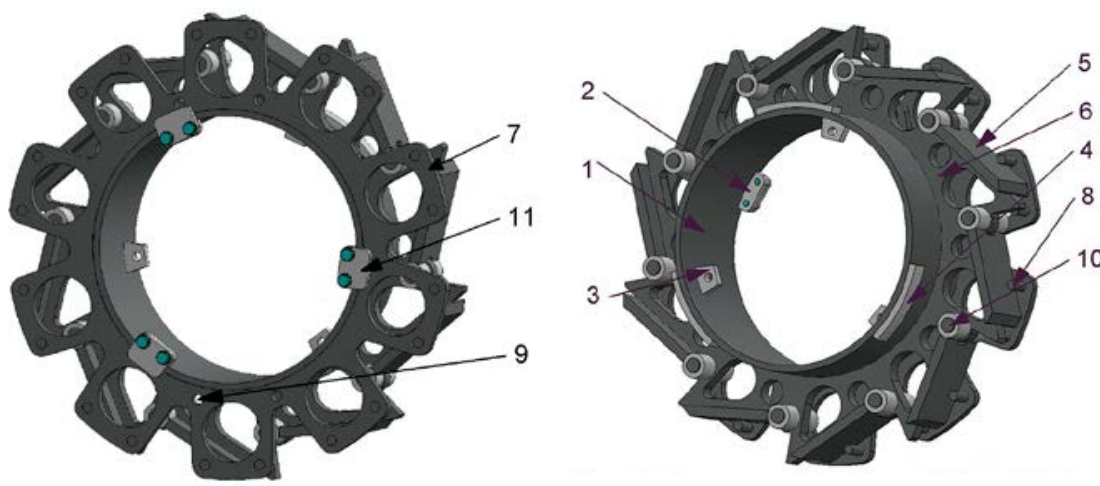

Figure 2a, b Wheel equipped with auto-extensible blades 1 - support tube, 2 - locking tab, 3 - bracket fastening the mechanism to the wheel disc, 4 - spacer plates, 5 - blade, 6 - driving disc, 7 - blade control disc, 8 - guide pin, 9 - locking hole, 10 - blade pin, 11 - buffer plate



Figure 3 Wheels equipped with auto-extensible blades mounted on the tractor rear wheels

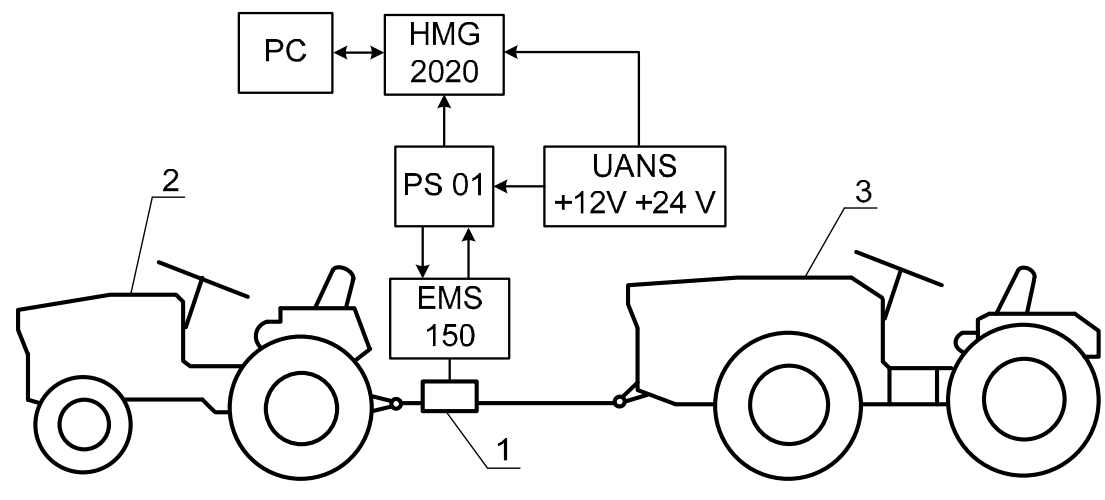

Figure 4 Connection diagram of drawbar pull measurement of Mini 070 1 - drawbar pull sensor EMS 150, 2 - measured tractor Mini 070, 3 - loading tractor T4K10, HMG 2020 - digital recording device, UANS - universal battery source, PC - personal computer, PS 01 - junction box

screws to the locking tabs (2), fix the blade control disc on the support tube.

\section{Tractor loading during the measurement of drawbar pull}

The drawbar pull measurement of the tractor Mini 070 is performed by means of a tensometric force sensor marked as 150 EMS, as shown in Figures 4 and 5 . The force sensor is connected between the loading tractor $\mathrm{T} 4 \mathrm{~K} 10$ and the measured tractor MINI 070 through a chain, Figure 5. Measurements were performed on two surfaces - the soil and grass. A digital recording unit HMG 2020 (Hydac GmbG, Germany) was used to record electrical signals from the force sensor. A description of HMG 2020 is presented in the work published by Kosiba et al. (2011).

The drawbar pull measurement of Mini 070 is arranged chronologically in the following points:

- connecting the tractor T4K10 to the MINI 070 hitch by the chain, which is connected to the force sensor of drawbar pull;

- preparing the measuring device HMG 2020 for measuring;

- measuring the maximum drawbar pull while loading the tractor T4K10 up to a $100 \%$ slip of the Mini 070's driving wheels;

- measurements carried out on the soil and grass, with different versions of driving wheels (tyres, wheels equipped with auto-extensible blades) in the first and second gear.

\section{Results and discussion}

The results presented in Figure 6 show the curves of the maximum drawbar pull in the first gear on the soil and grass. It shows only the selected time period of two seconds, which represents an increase in drawbar pull and the culmination of the maximum drawbar pull. The total measurement time of drawbar pull was 20 seconds. Drawbar pull begins when all measurements are at about the same level of 1,000 N, corresponding to the pulling of released T4K10 in neutral. In the field of increased drawbar pull, there were recorded different characteristics given by the type of base. The highest oscillation of drawbar pull was observed when using the wheel equipped with auto-extensible blades 


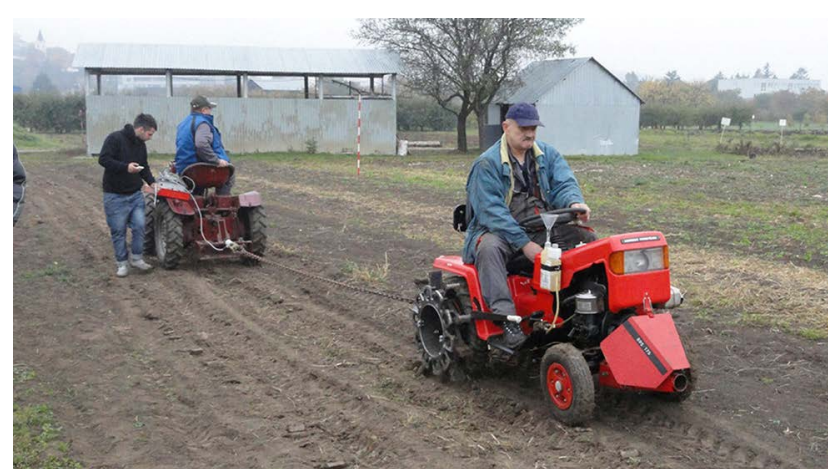

Figure 5 Measurement of drawbar pull

on a grassy surface. In this case, the short-term increase of drawbar pull is given by engagement of blades on a firmer grassy surface as opposed to the field surface. In case of tyres and steel boots, the increase of drawbar pull is smoother due to a more uniform arrangement of tyre contact surfaces and of boots' blades on the wheel circumference.

The values in Tables 2 and 3 clearly show the increasing of drawbar pull of wheels equipped with auto-extensible blades in comparison with tyres. The values demonstrate the increasing of drawbar pull at an average of $70 \%$ on the soil and $80 \%$ on grass. In the second gear, the tractor reached higher drawbar pull with all variants of driving wheels at an average of $3 \%$. This increase is possible only on the soil and grass where engine power is better distributed on a yielding surface. In the first gear, the engine has a sufficient power for slipping of driving wheels; however, in this condition,

Table 1 Specifications of tractors

\begin{tabular}{|c|c|c|}
\hline \multicolumn{3}{|c|}{ Tractor Mini 070} \\
\hline Year of manufacture & \multicolumn{2}{|c|}{1989} \\
\hline Construction weight & \multicolumn{2}{|c|}{$310 \mathrm{~kg}$} \\
\hline \multirow{4}{*}{$\begin{array}{l}\text { Driving speed } \\
\text { at rated engine } \\
\text { speed 3,600 rpm }\end{array}$} & $1^{\text {st }}$ gear & $1.53 \mathrm{~km} / \mathrm{h}$ \\
\hline & $2^{\text {nd }}$ gear & $2.72 \mathrm{~km} / \mathrm{h}$ \\
\hline & $3^{\text {rd }}$ gear & $4.96 \mathrm{~km} / \mathrm{h}$ \\
\hline & $4^{\text {th }}$ gear & $14.40 \mathrm{~km} / \mathrm{h}$ \\
\hline Clutch & \multicolumn{2}{|c|}{$\begin{array}{l}\text { Dry, single plate, } \\
\text { with direct mechanical shutoff }\end{array}$} \\
\hline \multirow{4}{*}{ Engine } & \multicolumn{2}{|c|}{$\begin{array}{l}\text { Petrol, four-stroke, } \\
\text { air-cooled Briggs \& Stratton }\end{array}$} \\
\hline & Number of cylinders & 1 \\
\hline & Displacement & $400 \mathrm{~cm}^{3}$ \\
\hline & $\begin{array}{l}\text { Max. performance / } \\
\text { rotation speed }\end{array}$ & $8 \mathrm{~kW} / 3,600 \mathrm{rpm}$ \\
\hline \multicolumn{3}{|c|}{ Tractor T4K10 } \\
\hline Year of manufacture & \multicolumn{2}{|c|}{1966} \\
\hline Construction weight & \multicolumn{2}{|c|}{$820 \mathrm{~kg}$} \\
\hline \multirow{4}{*}{ Engine } & \multicolumn{2}{|c|}{ Two-stroke, air-cooled diesel } \\
\hline & Number of cylinders & 1 \\
\hline & Displacement & $900 \mathrm{~cm}^{3}$ \\
\hline & Max. performance & $10 \mathrm{~kW}$ \\
\hline
\end{tabular}

Table 2 Maximum drawbar pull of Mini 070 on the soil

\begin{tabular}{|c|c|c|c|c|}
\hline & \multicolumn{2}{|c|}{ Tyres } & \multicolumn{2}{|c|}{$\begin{array}{c}\text { Wheels equipped } \\
\text { with auto-extensible blades }\end{array}$} \\
\hline & $1^{\text {st }}$ gear & $2^{\text {nd }}$ gear & $1^{\text {st }}$ gear & $2^{\text {nd }}$ gear \\
\hline \multirow{20}{*}{ 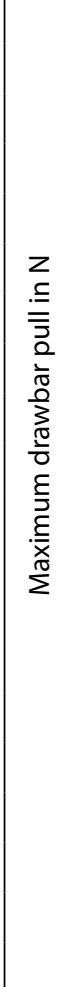 } & 1,796 & 2,486 & 4,046 & 4,028 \\
\hline & 1,796 & 2,486 & 4,064 & 4,058 \\
\hline & 1,808 & 2,504 & 4,094 & 4,064 \\
\hline & 1,814 & 2,510 & 4,094 & 4,064 \\
\hline & 1,832 & 2,510 & 4,112 & 4,112 \\
\hline & 1,832 & 2,510 & 4,130 & 4,124 \\
\hline & 1,850 & 2,534 & 4,130 & 4,160 \\
\hline & 1,862 & 2,534 & 4,166 & 4,184 \\
\hline & 1,880 & 2,540 & 4,208 & 4,196 \\
\hline & 1,898 & 2,570 & 4,214 & 4,208 \\
\hline & 1,910 & 2,570 & 4,244 & 4,214 \\
\hline & 1,976 & 2,606 & 4,244 & 4,226 \\
\hline & 1,976 & 2,606 & 4,316 & 4,334 \\
\hline & 2,000 & 2,624 & 4,328 & 4,352 \\
\hline & 2,030 & 2,660 & 4,382 & 4,472 \\
\hline & 2,030 & 2,708 & 4,400 & 4,520 \\
\hline & 2,036 & 2,720 & 4,412 & 4,550 \\
\hline & 2,048 & 2,738 & 4,448 & 4,616 \\
\hline & 2,060 & 2,738 & 4,484 & 4,718 \\
\hline & 2,138 & 2,756 & 4,484 & 4,820 \\
\hline
\end{tabular}

Table 3 Maximum drawbar pull of Mini 070 on grass

\begin{tabular}{||c||c|c|c|}
\hline \multicolumn{1}{|c||}{} & \multicolumn{2}{c|}{ Tyres } & \multicolumn{2}{c|}{ Wheels equipped } \\
with auto-extensible blades
\end{tabular}




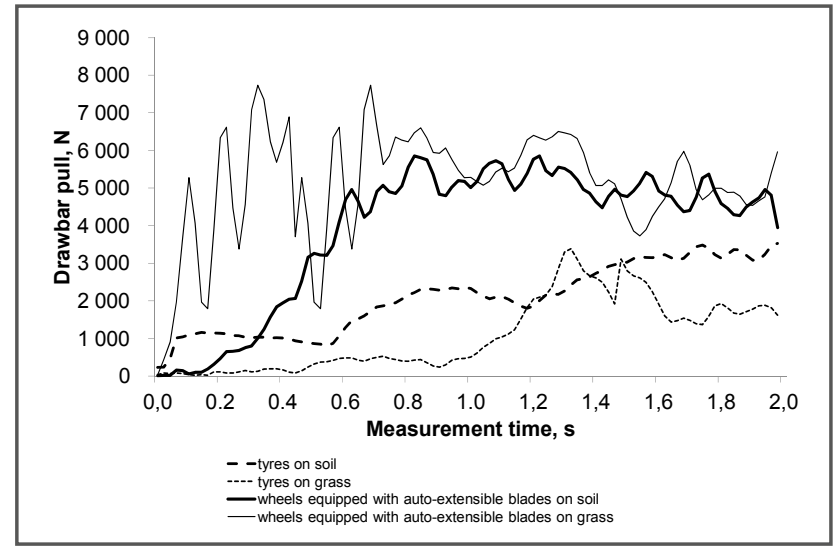

Figure 6 Course of drawbar pull of Mini 070 on the soil and grass

it shows a lower drawbar pull in all cases. These findings clearly confirm the theoretical basis for traction of wheel on a yielding surface. The higher the stiffness of the base, the higher drawbar pull is reached by the tractor when using the blade wheel, which needs a higher soil stiffness next to the wheel for reaching a higher drawbar pull.

\section{Conclusion}

Measurements were carried out in October 2012 at an average soil moisture of $17 \%$ on Chernozem, with an average bulk density of $1.33 \mathrm{~g} / \mathrm{cm}^{3}$. The soil was after harvesting of cucumbers and was relatively wet despite a dry weather. The measurement of drawbar pull was performed by the measuring and recording device Hydac 2020. The measurement of drawbar pull, or loading of the small tractor Mini 070, was performed by T4K10, by gradually loading up to a $100 \%$ slip of driving wheels, as shown in Fig. 5. With wheels equipped with auto-extensible blades, which can be used even for heavier tractors, a benefit is in an improved self-cleaning ability of wheel blades and that they can be folded easily by driving backwards. Following the completion of work and upon arrival at yard, they must be thoroughly cleaned, preferably by water pressure, because the drying clay may cause no-tipping of blades. Finally, the fact that speaks in favour of boots should be noted. Although V-shape blades had the same traction area as extensible blades, with wheels equipped with extensible blades also tyres were engaged and still had comparable drawbar pull results.

At the present, the trend of tractor design is aimed at high universality and possibility to equip the tractor with various attachments (Hujo et al., 2012). Wheels equipped with auto-extensible blades can be manufactured for various types of tractor wheels.

\section{Acknowledgements}

Supported by the Ministry of Education of the Slovak Republic, project VEGA No 1/0857/12 'Reduction of unfavorable impacts of agricultural and transport machinery on environment ${ }^{\prime}$

\section{References}

HUJO, Ł. - KOSIBA, J. - JABLONICKÝ, J. - DRABANT, Š. 2012 a. Theoretical design of a laboratory test device for the testing of tractor hydraulics. In Technics in Agrisector Technologies 2012. Nitra : SUA, pp. 68-73.

HUJO, L. - KOSIBA, J. - JABLONICKÝ, J. - TKÁČ, Z. 2012b. Measurement of load characteristics of tractor three-point hitch. In Technics in Agrisector Technologies 2012. Nitra: SUA, pp. 4-10.

JABLONICKÝ, J. - HUJO, L'. - TKÁČ, Z. - KOSIBA, J. 2012. Analysis of the force and kinematic load of the differential planetary transmission. In Technics in Agrisector Technologies 2012. Nitra : SUA, pp. 25-32.

KOSIBA, J. - TKÁČ, Z. - HUJO, L. - BUREŠ, L. 2012. Operating modes of hydraulic circuit of tractor Zetor Forterra 114 41. In Acta Technologica Agriculturae, vol. 14, no. 2, pp. 46-49.

MÜLLEROVÁ, D. - JABLONICKÝ, J. - HUJO, L.. - TKÁČ, Z. - KUČERA, M. - KOSIBA, J. 2012. Measurement of operating parameters and emissions of tractor with diesel oil and biofuel. In TEAM. Osijek-Baranja : University of Josip Juraj Strossmayer, vol. 4, no. 1, pp. 299-302.

SEMETKO, J. - JANOŠKO, I. 1998. Physical characteristics of soil under tires of vehicles. In New Challenges in Agriculture with respect to Joining the European Union : $27^{\text {th }}$ International Scientific Conference. Mosonmagyaróvár: Pannon University, pp. 1197-1202. SEMETKO, J. - JANOŠKO, I. - PERNIS, P. 2004. Determination of power of multidrive vehicles. In Acta Technologica Agriculturae, vol. 7, no. 1, pp. 20-23.

SCHULER, R.T. - CASADY, W.W. - RAPER, R.L. 2000. Soil compaction. In Conservation Tillage Systems and Management, MWPS-45, $2^{\text {nd }}$ ed., p. 74.

SLOBODA, A. - FERENCEY, V. - HLAVŇA, V. - TKÁČ, Z. 2008. Construction of tyres and crawlers vehicles. Textbook, $552 \mathrm{pp}$.

\section{Contact address:}

Ing. Rudolf Abrahám, PhD., Ing. Radoslav Majdan, PhD., Ing. Miroslav Mojžiš, PhD., Department of Transport and Handling, Faculty of Engineering, Slovak University of Agriculture in Nitra, Tr. Andreja Hlinku 2, 94976 Nitra, Slovak Republic, e-mail: rudolf.abraham@uniag.sk 